prof. dr. Colin

Titmus

School of

Education,

London

\title{
O IZPOSOJI KULTURE IN O NADVLADI TUJE KULTURE $\checkmark$ DOPOLNILNEM IZOBRAŽEVANJU
}

\section{POVZETEK}

Pisec razpravlja o izposoji kulture med državami ali narodi na področju dopolnilnega izobraževanja odraslih. Poudari, da so nekateri pisci sprva zmotno primerjali model začetnega izobraževanja in prenos kulture, $k i$ se vrs̆i tam $z$ dopolnilnim izobraževanjem. Začetno izobraževanje, ki ga zasnuje država, je moč obravnavati kot celoto in ga tudi kot celoto skupaj s kulturo, na kateri temelji, prenesti na tuja tla. Dopolnilno izobrǎ̌evanje odraslih zasnuje skupina posameznikov. Še več, dopolnilno izobraževanje ne velja za celo državno področje, tako kot začetno. Pisec dokazuje, da izposoja kulture obstaja, pri čemer gre v novem kulturnem kontekstu bodisi za preprost prenos kulture iz enega izobrǎ̌evalnega sistema $v$ drugega, za prilagoditev izposojene kulture drugemu sistemu ali za preobrazbo izposojene kulture $v$ nekaj novega. Kulturo si v izobraževanju lahko izposojamo po lastni volji ali pa nam jo vsilijo. $V$ slednjem primeru najpogosteje, a ne vedno, budi odpor pri prejemnikih.

Ključne besede: kultura, izposoja kulture, preobrazba kulture, nadvlada kulture, dopolnilno izobraževanje, začetno izobraževanje

$\mathrm{K}$ omunikacija med kulturami ni nova, toda danes zaradi razvoja tehnologije nekatere kulture hitreje in pogosteje prihajajo $\mathrm{v}$ stik ter vplivajo ena na drugo. Posledica tega je, da so vse bolj odvisne ena od druge. Pripadniki posameznih kultur si tako želijo izvedeti več o kulturi drugih in želijo si, morda celo bolj kot nekoč, drugim pripovedovati o svoji. Vsi, ki se udeležujemo mednarodnih konferenc, smo tako občasno izpostavljeni predstavitvi tega, kar drugi počno $\vee$ svojih deželah. "Kaj počnemo pri nas« je torej priljubljena tema mednarodnih srečanj. Vsi smo se že kdaj vpletli v takšno početje, ki ima visto večplastnih, četudi pogosto ne povsem jasnih ciljev. Pravzaprav bi veljalo dodobra raziskati, kakšno funkcijo imajo takšni prispevki in kako jih pripraviti. Takšno raziskovanje bi osvetlilo vprašanje komunikacije med kulturami.

\section{POSNEMANJE KULTURE}

DRUGIH V ZAČETNEM ŠOLSKEM IZOBRAŽEVANJU IN V IZOBRAŽEVANJU ODRASLIH

Moj namen ni še nadalje razpravljati o tej temi, kajti želim se posvetiti nekemu dru- 
gemu vidiku komunikacije med kulturami in njegovim posledicam. Želim preučiti, kaj se zgodi, kadar zato, ker želimo spoznati neko kulturo, ali zato, ker opazujemo neko kulturo, pričnemo - obdani s svojo lastno kulturo - to kulturo posnemati. To lahko počnemo, ker je takšna naša volja, ali zato, ker so nam drugi tako ukazali, četudi se njihovi nameni pri tem zdijo nejasni. Takšne reči se godijo na vseh področjih družbenega življenja in morda bomo odkrili tudi kakšna splošna načela, po katerih se odvijajo. Ker pa še zdaleč nisem vseved, se bom moral omejiti na razmislek glede tega zgolj na področju dopolnilnega izobraževanja, področju, ki ga edinega bolje poznam in ki sem ga edinega dovolj izkusil, da si lahko dovolim nekaj misli. Pa še te bodo razmišljujoče narave, kajti $v$ njih bo enako število vprašanj kot hipotez.

\section{ZGODOVINA IN NARAVA MEDSEBOINIH KULTURNIH VPLIVOV}

Zgodovina medsebojnih kulturnih vplivov je zelo dolga (Holmes, 1981). V ameriških mestih so že leta 1814 pričeli posnemati britanske šole za odrasle (Pole, 1814). Pod močnim vplivom Georgesa Birbecka je nato leta 1824 Charles Dupin pričel $z$ Večerno solo za odrasle na Nacionalnem konzervatoriju umetnosti in poklicev (fr. Conservatoire national des arts et metiers) (Titmus, 1967). $\checkmark$ svoji primerjalni študiji o izobraževanju odraslih pa George Bereday celotno 19. stoletje poimenuje »stoletje izposoje«, rekoč, da »so s primerjavo informacij pričeli zato, da bi najboljšo prakso posameznih držav lahko presadili drugam« (Bereday, 1964). Na prelomu iz 19. v 20. stoletje sta Michael Sadler $\checkmark$ Veliki Britaniji in William Torrey Harris v Združenih državah Amerike - kasneje so to storili tudi drugi primerjalni andragogi - zanikala, da bi bilo moč poimenovati lastnika posa- mezne izobraževalne prakse ali da bi si bilo moč takšno prakso celo izposoditi od katere druge države $z$ namenom, da jo vsadimo na tla svoje. Umni duhovi, kot so Sadler, Friedrich (1961), Isaac Kandel (1933), Nicholas Hans (1958) in Pedro Rossello (1960), pa Kaj se zgodi, č in ko začnemo posnemati tujo kulturo?

so se vendarle o nečem sporazumeli. Namreč, da je izobraževalni sistem proizvod družbe, posledica medsebojnega vpliva med njim in družbo, družbo, sredi katere je in kateri služi. In družba je odločilnega pomena za njegovo čilost. Če bi namreč hoteli posamezen izobraževalni sistem premestiti $v$ neko drugo družbo, bi to pomenilo, da smo mu posekali korenine, mu onemogočili, da se hrani, mu naložili, naj žıvi od virov, ki jim je le slabo prilagojen in ki jim ničesar ne dolguje. In ker je, tako pravijo, izobraževanje neke države celota, ker je zraslo iz svojih medsebojno tesno povezanih delov, si nikakor ni moč zamisliti, da bi posamezni

lzobraževalni sistem je vselej proizvod točno določene družbe. deli takšne celote lahko samostojno zaživeli $\checkmark$ neki drugi državi. In če zdaj povzamemo Sadlerjeve besede:

Bliže današnjemu času je Brian Holmes, ki trdi, da ni mogoče in ni prav, če si izobraževalni sistemi ne bi izposojali od drugih kultur, pa vendar ni prepričan, da je selektivna izposoja te vrste utemeljena ali mogoča, opozarjajoč pri tem, da potrebujemo o tem predmetu več znanja, preden se ga dejansko lotimo (Holmes, 1981).

"Med izobraževalnimi sisteni sveta se ni
moč sprehajati, kakor se otrok sprehaja po
vrtu, nabirajoč cvetje z enega grma in listje
z drugega, upajoč pri tem, da bo nabrano
moč zlepiti in zasaditi v domača tla in da
bo iz vsega pognala živa rastlina« (Sadler,
1900 ).


Ponudba učnih priložnosti $\mathrm{v}$ izobraževanju odraslih je nekaj povsem posebnega in se, tako kot $v$ formalnem izobraževanju, oblikuje glede na značilnosti in potrebe dežele, pa vendar tudi glede na manjša zemljepisna področja in glede na manj številne populacije. Tedaj, tako se zdi, je izposoja kulture še manj primerna in zaželena kot v primeru formalnega, šolskega izobraževanja.

Izposoje kulture $v$ izobraževanju ni več moč preprečiti.
Domala vsi, ki so to vprašanje preučevali, so primerjali sisteme formalnega začetnega izobraževanja, $v$ katerega vključujemo tudi visokošolsko izobraževanje, toda izobraževanja odraslih in dopolnilnega izobraževanja odraslih se pri tem skorajda niso dotaknili. Malo primerjalnih raziskovalcev se je posvetilo izobraževanju odraslih in še ti se niso dotaknili vprašanja izposoje med kulturami $v$ danem kontekstu (Titmus, 1989). Ker niso imeli na razpolago drugih modclov, so se zatekli k primerjavi formalnega šolanja, pri čemer so dokaj nekritično predvidevali, da bo splošna načela in prakso $s$ tega področja moč prenesti na področje njihovega preučevanja. Glede izposoje kultur pa so morda imeli prav.

Izposoja kulture na področju izobraževanja odraslih ni povsem primerna, saj izobraževanje odraslih raste predvsem iz poznavanja posebne kulture posameznih ciljnih skupin. Le če zadovoljimo to potrebo, smemo izobraževanje odraslih povezati z drugimi, tujimi kulturami.' Spominjam se univerzitetnega profesorja, ki je nekako pred tridesetimi leti na neki konferenci trdil, da je britansko izobraževanje odraslih tako močno povezano z lastno kulturo, da bi bilo nevredno, če bi izobraževalci odraslih kakorkoli preučevali tuje kulture, kaj šele, da bi si jih izposojali. Še manj je omenjal, da bi se tujci lahko učili od Britancev.

$\breve{C}$ e torej izposoja kulture $v$ šolskem in visokošolskem izobraževanju, pa tudi $v$ izobraževanju odraslih, ni primerna, velja upoštevati dejstvo, da ni v vseh primerih tako. Trditvi, da je izposojanje kulture neprimerno, nasprotuje med drugim dejstvo, da so se univerze za tretje življenjsko obdobje - prvo so zasnovali v Toulousu - razširile po Evropi in to $z$ večjim ali manjšim uspehom (Withnall in Kabwasa, 1985, str. 1651-1654). Po tistem, ko so na Nizozemskem ugotovili, da imajo veliko funkcionalno nepismenih, so Nizozemci, da bi rešili to vprašanje, našli rešitev pri Britancih in so uvedli metodo poučevanja »eden $z$ enim《 (angl. one-to-one). Dejstvo, da so tak način poučevanja na Nizozemskem kmalu opustili in ni bil več prevladujoč način poučevanja funkcionalno nepismenih, pa ni posledica nizozemskih ali britanskih kulturnih posebnosti, četudi so tudi Britanci kmalu opustili tak način poučevanja. V obeh državah pa so namreč hitro ugotovili, da so se prenaglili in da njihova ciljna skupina pravzaprav dokaj dobro sprejema to metodo poučevanja.

Glede na to, da se izposoja kulture dogaja, lahko domncvamo, da tisti, ki si jo izposojajo, najverjetneje res - žal - niso brali Sadlerja in drugih, ali pa se stemi pisci ne strinjajo oziroma so prišli pod vpliv drugačnih trditev. Vse je mogoče. Zdi pa se, da izposoje kulture ni moč preprečiti. Kolikor vem, ni evropske države, ki bi jo preprečcvala z zakoni in pravili. Prav nasprotno. Ko se izposoja ustali, je zakonodajalci in šolske oblasti ne morejo več zajeziti. Andragogi in izobraževalci odraslih pa so se tudi sami zavzeli za to, naj se tuja kultura pretaka $v$ domače izobraževanje tchtno in razsodno, kolikor je le mogoče. Vsekakor s premislekom!

Primerjalne študije izobraževanja odraslih načeloma vplivajo na izobraževalno prakso in tako je ena pomembnih nalog raziskovanja, da opozarja na procese izposoje kulture in na dejavnike, ki vplivajo nanje. Na takšni podlagi je mogoče oblikovati tudi učinkovito politiko izobraževanja. 


\section{OPREDELITEV KONCEPTOV RAZPRAVE}

$\mathrm{V}$ tem prispevku obravnavam izposojo kulture in nadvlado tuje kulture $v$ dopolnilnem izobraževanju, pri čemer soglasja o konceptih te razprave, kot so »kultura«, »dopolnilno izobraževanje «, »izposoja in »nadvlada «, nismo dosegli. Zatorej bi veljalo najprej razjasniti to semantično polje. Vernon Mellisson glede kulture navaja Michaela Leirisa (1951), ki pravi: »Kultura neke družbene skupnosti je seštevek načinov življenja te družbe ... Zajema vse, kar je družba podedovala, ali vse, kar je bilo njenim članom $s$ pomočjo družbene skupnosti predano ...« (Mellisson, 1975).

Po neki drugi opredelitvi je kultura »skupni seštevek kolektivnih duševnih in duhovnih artefaktov, tj. sistemov simbolov, idej, prepričanj, estetskih zaznav, vrednot itd. ter prepoznavnih načinov obnašanja, kot so

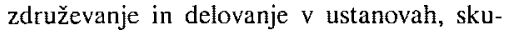
pinah, opravljanje obredov, organiziranje itd. Do načinov obnašanja pride sredi sprememb, ki jih sleherni narod nenehno doživlja, zaradi tega spremenjene načine obnašanja pa predaja naslednjim rodovom. Prihaja pa tudi tako, da se sredi dlje časa trajajočih dejavnosti in življenjskih razmer naključno povežemo in delujemo, pri čemer prihaja do naključnih posledic (Fletcher, 1988).

Obe opredelitvi sicer vsebujeta niz sestavin, ki skupaj tvorijo kulturo, a vendar sta pomanjkljivi, kajti bralcu prepuščata, da se odloči, kaj pravzaprav pomeni »družba in kdo so pravzprav »mi«. Zaradi tega trditve primerjalnih andragogov glede kulturnih posebnosti izobraževalne prakse niso dovolj tehtne. Sadler, denimo, pravi: "Če naj bo izobraževanje odraslih dobro, mora zrcaliti življenje naroda in njegov značaj « in še »Noben narod, ki malce posnema nemško organiziranost, ne more upati, da bo $s$ tem lahko poustvaril nemške institucije« (Sadler, 1902, str. 162, 44). Še več, za Sadlerja je država enaka naro-

du. To istovetenje obeh pojinov je že v njegovih časih zbujalo dvom, danes pa še toliko bolj, če pomislimo na primer na spremembe $v$ Vzhodni Evropi ali pa na vprašanje izgradnje narodov v državah tretjega sveta.

Kasneje so bili Hans, Kondel, Schneider in Sadler prepričant, da izobraževalnemu sistemu vdihne življenje nacionalni duh, različen od nacionalnega duha drugih držav. Brez takšnega duha izobraževalni sistemi zgubijo vrednost, tako da niti njihove celote niti posameznih delov ni mogoče presaditi drugam in jih tam uporabiti. Našteti pisci so očitno verjeli $v$ pomen nacionalnih držav, koncept, ki je pogosto zgrajen na trhlih temeljih (glej Hobsbaum, 1990), a so ga $v$ njihovem casu dobro razumeli. Njihova napaka je bila $v$ tem, da so mislili, da je ta koncept univerzalen, četudi mnoge države tudi tedaj niso bile tako organizirane, denimo Avstro- Ogrsko cesarstvo ali Turčija. Ti misleci so posplošitve izvedli iz prakse evropskih in

Izobraževalnemu sistemu vdihne življenje šele nacionalni duh. severnoameriških držav. Za svojo obravnavo so izbrali predvsem države $z$ naprednim izobraževalnim sistemom in izobraževalnimi ustanovami. Čeprav so bile njihove posplošitve uporabne za te države, pa bi, preden njihove trditve sprejmemo kot splošno veljavne in preden sprejmemo njihov vpliv na izposojo kulture - ti misleci tega namreč niso storili-, vedarle bilo smiselno preveriti, $v$ kolikšni meri se njihove teorije lahko nanašajo tudi na države z manj razvitim izobraževalnim sistemom bodisi v Evropi ali v tretjem svetu.

Če sprejmemo trditev, da vse dobro izobraževanje preveva kultura, sredi katere izobraževanje obstaja, morda prenaglo sklepamo, da je kultura pravzaprav kultura posamezne države, in če ne države, pa naroda.

V muslimanskih pokrajinah Srednjega Vzhoda in Severne Afrike, denimo, so meje kulture hkrati tudi meje držav, kot so Libija, Tunizija, Maroko, Egipt, Savdska Arabija itd,, ali meje 
naroda ali islama. $V$ francosko ali angleško govorečih deželah Afrike so morda kulture, ki so jih sem zanesli kolonizatorji, tu danes manj navzoče kot muslimanska kultura Srednjega Vzhoda, vendar še zmeraj dovolj močno in skupaj z izvorno kulturo vsake posamezne države. Podobno je kubansko izobraževanje morda bolj proizvod marksizma kot kulture kubanskega naroda.

Vse kaže, da lahko vztrajamo pri trditvi, da je v katerikoli družbi izobraževanje proizvod in hkrati sestavni del različnih kultur, kulture države ali njenega dela - kot denimo na Škotskem - ali nacionalne zavesti pa tudi ideologije ali religije. $V$ posameznih družbah

\section{Skozinačin} organiziranosti izobraževanja se izraža vpliv države in njene kulture. je delež vpliva različnih kultur različen, pri čemer je $v$ nckaterih najmočnejši vpliv države, $v$ drugih narodna zavest, spet $v$ drugih religiozno ali ideološko verovanje. Vpliv je čutiti na različnih ravneh, npr. na duhovni ali materialni ravni, ali pa je vpliv kulture pomenljiv v različnih sferah družbenega življenja in ga je tako čutiti tudi v organizaciji izobraževanja in $v$ pedagogiki.

V načinu, kako je organizirano izobraževanje, se $\mathrm{v}$ večini družb kaže vpliv države in njene kulture, ki prevladuje. Ta določa izobraževalno prakso in strukturo. Kadar primerjalni andragogi pišejo o izposoji kulture, imajo $v$ mislih prenos enega državnega sistema $v$ drugega, četudi države ne omenjajo in tudi o narodu ne govorijo. Državna kultura ima svoje posebnosti, če je hkrati proizvod in izraz drugih kultur, ki so se razlile prek meja posamezne države, potem je morda izobraževalna praksa, ki tam nastane, manj posebna, kot se na prvi pogled zdi, in tedaj izposojanje kulture med državarni ni tako močno nenaravno.

Koliko je takšno izposojanje kulture izvedljivo, je odvisno od tega, kako pojmujemo izposojanje. Lahko rečemo, da oni, ki pričnejo $\mathrm{z}$ izposojo kulture, nameravajo to početi dolgo in ne zgolj začasno. Izposojenega niso voljni vrniti, četudi $v$ vsakdanji govorici izposoja pomeni nekaj začasnega, nekaj, kar je treba vrniti. Pa vendar si glede izposoje kulture postavljamo vsaj eno pomembno vprašanje: Ali bosta kljub presaditvi kultura ali institucija ostali nespremenjeni? Različni misleci so bili mnenja, da je izobraževanje treba ohraniti v celoti ali pa se bo značaj izobraževanja, ki temelji na posamezni kulturi, ob presaditvi spremenil. Tako naj bi izposoja tekla tako, da kljub presaditvi izobražcvanje ostanc nespremenjeno, če ne želimo, da pride do izničenja kulture, na kateri temclji (Holmes, 1951). Ti pisci so mnenja, da bi izposoja, če bi bila mogoča, morala potekati tako, da izobraževanje ostane nespremenjeno. $V$ nasprotnem primeru je, po njihovem mnenju, prizadeta njegova bit, ta bit izgine ali pa se izobraževanje spremeni tako, da ga ni več moč prepoznati.

Sam sem mnenja, da ob izposoji kulture in ob presaditvi te $v$ nov kulturni kontekst zmeraj prihaja do sprememb. Pri tem se sprašujemo, katere spremembe so mogoče in kako daleč lahko s spremembami gremo. Skrajno mnenje je, da so spremembe lahko kakršnekoli vrste in da so lahko velike, kolikor želimo, da le služijo interesom sistema, ki si kulturo izposoja in da nam pri tem ni pomembno, če se $s$ tem sistem spremeni, spremeni tako

Izposojo kulture pojmujemo hkrati kot proces in kot njegov nasledek. Proces pomeni, da gre za presajanje izobraževanja in seveda kulture, ki je $v$ takšnem izobraževanju zajeta, iz ene družbe $v$ drugo. $\breve{C}$ gre za presajanje brez kakršnegakol prilagajanja kulture, tedaj teoretična vprašanja o utemeljenosti takega početja ali o pomenu izgube duha kulture navadno ne vzniknejo.

Bolj pa se zastavljajo povsem organizacijska vprašanja, če drugega ne, vprašanje o financiranju izobraževanja, ki je od dežele do dežele drugačno. 
močno, da ga ni več mogoče prepoznati. V takšnem primeru je proces izposoje pravzapray nekakšna preobrazba, ki teče pod vplivom različnih kultur, pri čemer sta neka izobraževalna praksa ali institucija $v$ neki družbi služili temu, da se je izposoja sploh lahko pričela in da se je $v$ družbi ust varilo nekaj novega. Mislim, da nihče od že omenjenih piscev, od Sadlerja do Holmesa, tej ugotovitvi ne bi nasprotoval. V njihovih očeh pa to ne bi bila več izposoja, marveč bi jih to le potrdilo v razmišljanju, da si kulture pač ni mogoče izposoditi.

Takšna izposoja se godi pogosto. Proces izposoje kulture lahko privede do nečcsa, kar je pravzaprav $\mathrm{v}$ marsičem podobno izvorni kulturi. V novem kulturnem kontekstu lahko izposojena kultura služi enakim namenom, kot jim služita praksa ali institucija, od koder je bila kultura izposojena, pa čeprav ni zmeraj tako. Lahko pa se zgodi, da ne služi namenu, zaradi katerega so kulturo presadili $v$ nov kontekst. $V$ osvetlitev te trditve navajam primer Grundtvigovih ljudskih visokih šol. Šlo je za izposojo iz rezidenčnega kolegija Oxbridge, ki je na Grundtviga naredil močan vtis, četudi so ljudske visoke šole močno drugačne, imajo drug namen oziroma so imele drug namen v Grundtvigovem času. Ko so ljudske visoke šole vzniknile na Danskem, pa lahko rečemo, da niso povsem izpolnile pričakovanj. Izposoja kuIture tako lahko vodi $\checkmark$ dve skrajnosti, bodisi v popolno preobrazbo sposojene kulture ali do nečesa, kar je bolj malo podobno izvorni izposojeni kulturi, ali pa $\vee$ danem kulturnem kontekstu privede do izobraževanja, ki vrši enake funkcije, kot jih je vršilo izobraževanje v prvotnem kulturnem kontekstu. Resnično gre za dve skrajnosti, a ne tudi edini možnosti. Med njima je še mnogo vmesnih rešitev.

Izposoja kulture ni zmeraj zavedna ali namenska, četudi v primeru, ko si želimo doseči, da bi proces dosegel najboljše rezultate, zavestno usmerjamo napore proti cilju in tedaj gre za zavesten proces izposojanja kulture. Lahko pa se zgodi, da tisti, ki si kulturo izposoja, ne ve, od kod kultura izvira. $\mathrm{V}$ primeru, da gre za nadvlado oziroma vsiljevanje tuje kulture, je še več možnosti, da izposojevalec izvora kulture ne pozna. Najnazornejši primer tega so kolonije, ki jim je kolonizator - najpogosteje Francija ali Anglija - vsilil tujo izobraževalno prakso, navadno svojo lastno. To so morali sprejeti domačini na svojem ozemlju. Pri tem velja poudariti, da fizična zasedba nekega ozemlja ni bistvenega pomena za kulturno nadvlado. ZDA so se na primer podale $\checkmark$ Latinsko Ameriko in drugam tako,

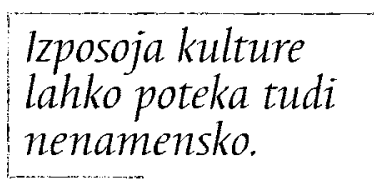

da so uporabile gospodarsko premoč. Bivša Sovjetska zveza je naredila nekaj podobnega znotraj svoje države pa tudi znotraj držav zaveznic. Vsiljevanje kulture pa je lahko tudi človekoljubno dejanje, če pri tem sledimo interesom prejemnika kulture.

$S$ Tomom Steelom sva opravila študijo o uvajanju Britanske univerze za izredne študente v Zahodni Afriki. Izkazalo se je, da se s takšno uvedbo poveča kulturna hegemonija močnejšega, tistega, ki $v$ njihovem kulturnem kontekstu drugim vsiljuje svojo ali neko drugo kulturo. Lahko bi dejali, da gre za neke vrste kulturni imperializem.

Vsiljevanje kulture drugim $v$ njihovem kulturnem kontekstu pomeni tudi nasilje in sproža odpor. Dogodki, ki so se odvijali po zlomu Sovjetske zveze zato, ker ni bilo

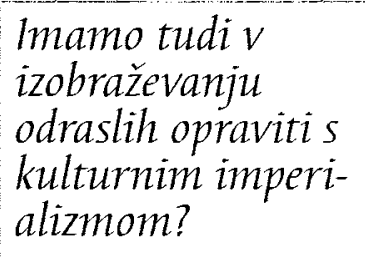
več represije, so pokazali, kako velika je bila kulturna prisila $v$ državah Vzhodne Evrope in kako močno so bile te države pripravljene upreti se vsiljeni jim kulturi, takoj ko je bilo mogoče. $V$ drugih predelih sveta, na primer $\checkmark$ kolonialni Afriki, bi bilo lahko podobno. Vendar so v kolonijah z navdušenjem sprejeli zahodno izobraževanje, saj se jim je zdelo, da 
Razlog za dolgoročno izposojo kulture razvitejših držav se kaže $v$ trdovratnem prepričanju, da obilje in bogastvo zahodnega sveta izvirata predvsem iz izobraževanja. Podobno izobraževanje naj bi torej povzročilo podobne učinke tudi $v$ tretjem svetu. $V$ takšnih razmerah je kritika kulturne nadvlade navadno usmerjena zgolj $\mathrm{k}$ motivom tistih, ki kulturno nadvlado vršijo, $\mathrm{k}$ praksi nadvlade, $k$ neobčutljivosti nadvladovanja, proti nadvladi $v$ celoti, a ne tudi proti izposoji kulture po lastni izbiri in iz lastne volje. Naloga raziskovalcev izposoje kulture je, da preučijo vlogo še vseh drugih dejavnikov, ki vplivajo nanjo.

jim bo zagotovilo družbeni položaj in bogastvo, kakršnega so uživali kolonizatorji. Ko pa so se ti umaknili, so nove neodvisne države močno kritizirale njihovo izobraževanje, o čemer pričajo tudi prispevki v številnih revijah s področja izobraževanja. Ko so bile bivše kolonialne države osvobojene političnih pritiskov in so lahko izbirale, pa so zelo pogosto nadaljevale $\mathrm{z}$ izposojo kulture od razvitejših držav.

Čctudi sem vprašanje izposoje kulture načel $z$ vidika izobraževanja odraslih, pa svoja razmišljanja lahko uporabim tudi v povezavi z drugimi področji izobraževanja. Nočem sicer zapisati, da $\mathrm{v}$ povezavi $\mathrm{z}$ vsem izobraževanjem, četudi bi izobraževanje konceptualno lahko obravnavali kot celoto. Zdi se $\mathrm{mi}$ bolj uporabno, če izobraževanje preučujemo $z$ vidika tega, kar ga je navdihnilo, $z$ vidika namenov, ki jih želi izpolniti, z vidika organizacije in procesov izobraževanja. Pa tudi ne poznam družbe, kjer bi izobraževanje delovalo kot celota. Če bi hoteli ustvariti posplošitve $o$ »celoti izobraževanja«, kot da takšna celota obstaja, bi to pomenilo, da prikrivamo raznolikost in neusklajenost izobraževanja ter povezanost tega z drugimi področji človekovega delovanja.

Povedano se tako nanaša bolj na dopolnilno kot na začetno izobraževanje. Oba izraza uporabljamo za poimenovanje tako procesa izobraževanja kakor tudi za poimenovanje vseh dejavnosti in organizacijskih načinov, $\mathrm{ki}$ proces omogočajo. Dopolnilno izobraževanje pojmujem kar se da široko in kot sopomenko izobraževanja odraslih, pa tudi kot proces, $\mathrm{ki}$ ga je UNESCO najbolje opredelil z naslednjimi besedami:

»... To je celota organiziranih izobraževalnih procesov, ne glede na vsebino, stopnjo in metodo izobraževanja, nc glede na to, ali je izobraževanje formalno ali ne, če je podaljšek ali nadomestek začetnega izobraževanja, ki poteka v osnovni šoli, srednji šoli ali na univerzi. To je tudi vajeništvo, kjer tisti, ki jih družba vidi kot odrasle, razvijejo sposobnosti, plemenitijo znanje, si pridobijo višje strokovne in poklicne kvalifikacije, ali pa so deležni usmeritve na novo pot, kar povzroči, da se spremenijo njihova stališča ali obnašanje, in kar pripomore $k$ dvojnemu cilju: $k$ vsestranski osebnostni rasti in $\mathrm{k}$ sodelovanju $v$ uravnoteženem, neodvisnem družbenem, ekonomskem in kulturnem razvoju.«(Titmus in drugi, 1979)

\section{ZNAČILNOSTI DOPOLNILNEGA IZOBRAŽEVANJA}

Ciljna skupina $v$ dopolnilnem izobraževanju zajema odrasle različne starosti, različno izkušene odrasle, ki so različnega socialnega porekla, odrasle $z$ različnimi družbenimi funkcijami, kar je drugače kot $v$ začetnem izobraževanju. Zato so tudi dejavnosti in načini, kako zadovoljimo njihove potrebe, različni od onih v začetnem izobraževanju. Res pa je, da postaja tudi dopolnilno izobraževanje vse bolj strukturirano, še zlasti zaradi vpliva države. Država sili ustanove začetnega izobraževanja, še posebno univerze, da uvedejo dopolnilno izobraževanje. Kljub vsemu pa je dopolnilno izobraževanje dosti manj vkalupljeno kot začetno izobraževanje $v$ šolah. Število študentov je nestalno, saj odrasli prihajajo $v$ vlogi študenta in jo zapuščajo, različno dolgo ostajajo študenti. Učne izkušnje so različno dolge in so različnih oblik, da bi tako lahko zadovoljili tudi razlicne potrebe ponudnikov 
izobraževanja in študentov. Mnoge ustanove dopolnilnega izobraževanja so nestalne, začasne, veliko njihovega dela je nestrukturiranega in poteka zunaj uradnih izobraževalnih ustanov. Za mnoge med njimi je dopolnilno izobraževanje obrobno. Mnoge se ga ne lotijo. V sleherni državi seveda obstajajo jedrne vsebine, ki jih ponujajo odraslim, kar kaže na delno trajnost potrcb in namena tega izobraževanja, a kadar se intelektualna moda, ekonomska in družbena vprašanja spremenijo, se obseg dopolnilnega izobraževanja močno poveča (glej Stock in Titmus, 1990).

Nacionalni sistemi začetncga izobraževanja so bolj strukturirani - ali vsaj naj bi bili bolj strukturirani! Njihova izobraževalna ponudba je manjša in bolj celovita, zato trditev, ki se nanašajo nanje - še posebno trditev glede odnosov med posameznimi deli začetnega izobraževanja in celoto -, nikakor ni moč uporabiti za to, da bi si 7 njimi razložili dopolnilno izobraževanje.

Ponudba dopolnilnega izobraževanja na univerzah je velika. Namen tega izobraževanja je, da pomaga reševati težave, da informira o posameznih vprašanjih, ne more pa se kaj dosti povezovati s preteklostjo ali s posebnostmi posameznih stanj. Vloga žensk, izobraževalne potrebe etničnih manjšin, dolgotrajno brezposelnih, preprečevanje jemanja mamil ali zlorabe mamil, manjšanje obsega obolenj $z$ aidsom, vse to so vprašanja, ki jih srečujemo $v$ dopolnilnem izobraževanju $v$ večini držav. Seveda pa je ponudba dopolmilnega izobraževanja $v$ vseh državah hkrati omejena in odprta, pri čemer upošteva indi- vidualne in kolektivne potrebe.

Toda če so si vprašanja dopolnilnega izobraževanja res povsod podobna, ali ni mogoče izobraževanja prilagoditi posameznikom? Že zdrava pamet pove, da bi to moralo biti mogoče, četudi ne zmeraj in povsod. Do kakšne mere so si dejavniki, ki v posamezni državi privedejo do nekega problema, podobni in do kakšne mere so enaki, je nadaljnje vprašanje. Pričakovali bi, da bo izobraževanje o takšnih skupnih vprašanjih $v$ posameznih državah podobno, kot posledica tega pa bo podobna tudi izposoja kulture v izobraževanju. Pričakovali pa bi tudi, da bo izposoje toliko več, kolikor manj je kultura posamezne države posebna.

Če se strinjamo, da so izobraževanje, deli izobraževanja in celota izobraževanja izraz kulture, tedaj je mogoče sklcpati, da skupni elementi, kažejo na to, da obstaja neka kultura. Ta kultura, pri čemer ne gre nujno za religiozno ali ideološko kulturo, preveva stanja posameznikov in zajema vsa stanja, $v$ katcrih se pojavljajo elementi izobraževanja. Primerjalna študija organizacije in strukture izobraževanja odraslih v Evropi (CRDASAEE) tako izkazuje močan vpliv evropske kulture na izobraževanja odraslih, tako $v$ Zahodni kakor tudi v Vzhodni Evropi. Tudi druge regionalne kulture in kulture $v$ deželah $v$ razvoju lahko podobno delujejo. Po vsem svetu razpredene sisteme osnovnih, srednjih in visokih šol je pojmovati kot izraz svetovne kulture. Dejstvo, da so ti sistemi bolj malo prilagojeni družbam, $v$ katerih so, kaže na to, da ni skladnosti med svetovno in drugimi

Začetno izobraževanje naj bi pripravljalo na življenje v posamezni družbi. Četudi se je mnenje o tem izobraževanju precej spremenilo, pa nemalokrat še zmeraj verjamemo, da začetno izobraževanje daje osnovo za vse življenje, enkrat za vselej. Njegov namen je namreč ustvariti takšne ljudi, da se bo z njimi ohranjala kultura države, v kateri sistem deluje. Dejavnosti dopolnilnega izobraževanja, ki so kompenzacijske narave in nadomeščajo tisto, kar je začetno izobraževanje wizpustilo«, služijo podobnim namenom kot začetno izobraževanje in so proizvod kulture, čctudi v nekaterih državah velja, da je vse izobraževanje isto kot kultura sama. 
kulturami države, naroda, regije, religije ali idcologije, ki tudi imajo pomembno vlogo pri oblikovanju izobraževanja.

Če povzamemo: že samo dejstvo, da $v$ dopolnilnem izobraževanju resnično obstaja izposoja kulture med državami in da je razmeroma uspešna, je dovolj za zavrnitev trditve, da ni mogoča. In še več, trditve, ki so bilc dolga leta $v$ veljavi in so nasprotovale dejstvu, da izposoja kulture obstaja, so izkazovale poenostavljen pogled na vpliv kulture na izobraževanje; da je izobraževanje pod vplivom zgolj ene kulture, ki je omejena $z$ mejami posamezne države, kar največkrat napak pojmujemo kot kulturo naroda. To je velika napaka! Pogled na posebnost državne kulture je pretiran, povezava $z$ drugimi kulturami pa prezrta. Trditev, da je izobraževanje $v$ neki državi celota, da ga preveva skupen duh in da posameznih delov tega izobraževanja ni moč brez škode ločiti od celote, je neutemeljena, ko gre za začetno izobraževanje, in je še bolj vprašljiva, ko gre za dopolnilno

$S$ procesi globalizacije se vse bolj približujemo globalni oz. svetovni kulturi. izobraževanje. Ce pojmujemo izposojo kulture kot poskus, da značilnosti ene države prelijemo $v$ drugo, pri čemer naj bi te značilnosti ostale nespremenjene, to pomeni, da imamo na ta pojav silno ozek pogled in da ne razumemo, kaj se v resnici dogaja.

Zdi se, da v nobeni državi dopolnilno izobraževanje $v$ praksi ne more biti celota. Povezave med izobraževalnimi ustanovami in povezave

Izposoja kulture lahko vodi tudiv preborazbo in rast. med funkcijami izobraževanja so rahle. Sestavine izobraževanja oblikuje država, v kateri se izobraževanje odvija, vendarle so lahko, in morda so vse bolj in bolj, pod vplivom drugih kultur. Te se prelivajo prek meja posameznih držav in narodov, kjer so nastale, pri čemer vpliva tega morda ni čutiti na natanko opredeljenem zemljepisnem področju. Kul- ture se prekrivajo, vplivajo druga na drugo in različni vidiki dopolnilnega izobraževanja so ob različnem času lahko različno pod vplivom različnih kultur, katerih izraz so. Te spremenljivke najverjetneje pomembno določajo naravo in obseg izposoje kulture.

\section{SKLEPNA BESEDA}

Dobro je, če izposojo obravnavamo kot proces in kot nasledek. Proces je lahko zgolj preprosto prenašanje izposojenega, lahko pa pomeni prilagajanjc izposojenega novim kulturnim razmeram, pri čemer je prilagajanje lahko tako veliko, da se pojavi preobrazba ali asimilacija izposojenega. V nekaterih primerih izposojanja ni več čutiti in nova kultura prežame organizacije in ustanove. Zdi se, da stopnja in narava delitve kulture med družbami darovalkami in družbami prejemnicami v marsičem določita, koliko mora biti prilagajanje poglobljeno, da bi bil prenos od ene do druge družbe uspešen. Nedvomno je medsebojno prilagajanje posameznih zahodnih evropskih držav in medsebojno prilaganje vzhodnih evropskih držav manjše, medtem ko je medsebojno prilagajanje zahodnih in vzhodnih evropskih držav že večje, prilagajanje evropskih in afriških držav pa še večje in še bolj poglobljeno.

Podobno kot druge dejavnosti dopolnilnega izobraževanja so tudi izposojo kulture zasnuli posamezniki ali skupine, nikakor pa ne država. Zdi se, da posegi države v dopolnilno izobraževanje niso vplivni, vendar je zmožnost države, da stvari spreminja, velika, in je doslej še nismo dovolj obravnavali. Lahko predvidevamo, da bodo nove članice Evropske unije vplivale na vse večjo izposojo kulture med državami. Primerjalni andragogi lahko $s$ svojimi študijami pripomoremo k temu, da ta poteka bolj sistematično in bolj utemeljeno. Če bodo države našo pomoč hotele uporabiti, pa je že drugo vprašanje. 


\section{LITERATURA IN VIRI}

Bereday, G. Z. F. (1964). Comparative Method in Education. New York: Holt, Rinehart in Winston.

Bullock, A., Stallybrass, O.,Trombley, S. (ur.) (1988). The Fontana Dictionary of Modern Thought. Ponatis. London: Fontana.

ECLE 1977-1981. Adult Education in Europe: Studies and Documents, 25 zvezkov. Praga: European Centre for Leisure and Education.

Flctcher, R. (1988). Culture. V Bullock, A., Stallybrass, O., Trombley, S. (ur.) London: Fontana.

Hans, N. (1958). Comparative Education. A Study of Educational Factors and Traditions. Drugi ponatis. London: Routledge in Kegan Paul.

Holmes, B. (1981). Comparative Education: Some Considerations of Method. London: George Allen in Unwin.

Husen, T., Postlethwaite, T. N. (ur.) (1985). The International Encyclopedia of Education. Dodatni zvezek 2. Oxford: Pergamon.

Kandel, I. L. (1933). Comparative Education. Boston, Mass: Houghton Miflin.

Mallinson, V. (1975). An Introduction to the Study of Comparative Education. Tretji ponatis. London, Heinemann.

Pole, T. (1814). History of the Origin and Progress of Adult Schools. Bristol.

Rama, G. W. (1985). Dependency Theory in Education. V Husen, T., Postlethwaitc, T. N. (ur.). The International Encyclopedia of Education. Oxford: Pergamon.

Rossello, P. (1960), La teoria de las corrientes educativas. Pariz: UNESCO.

Sadler, M. (1900). How far can we learn anything of practical value from the study of foreign systems of education? V Higginson, J. H. (ur.) (1979) Selections from Michael Sadler: Studies in World Citizenship. Liverpool: Dejall in Meyorre.

Sadler, M. (1902). The unrest in secondary education in Germany and elscwhere. V Board of Education Special Reports on Education Subjects. Zvezek 9, Education in Germany. London: HMSO.

Schneider, F. (1961). Vergleichende Erziehungswissenschaft. Heidelberg: Quelle in Meyer.

Stock, A., Titmus, C. (1990). Adult Education: Questions of Data, V Husen, T., Postlethwaite, T. N. (ur.) (1985), The International Encyclopedia of Education.

Dodatni zvezek 2, Oxford: Pergamon.

Titmus, C. (1967). Adult Education in France. Oxford: Pergamon.

Titmus, C. (1989a). Comparative Studics in Lifelong Education. V Titmus, C. (ur.), Lifelong Education for Adults: An International Handbook. Oxford: Pergamon. Titmus, C., Buttendahl, P., Ironside, D., Lengrand, P. (1979). Terminology of Adult Education. Pariz: UNESCO.
Withnall, A. M. E., Kabwasa, N. O. (1985). Education of the Elderly. $V$ Husen, T., Postlethwaite, T. N. (ur.) (1985), The International Encyclopedia of Education. Oxford: Pergamon

Besedilo je prevedla in priredita doc. dr. Dušsana Findeisen.

' $V$ ponazoritev te trditue navajamo sizobraževanje odraslih po franšizni pogodbiu, ki se vse bolj širi v Sloventiji in kjer gre za natančno, grobo in za našo kuluro neobčtutjivo prenašanje tuje kultue v naše okolje (op. prevajalke). 